\title{
Path Exploration on International Science and Technology Cooperation in the Construction of Silk Road Economic Belt
}

\author{
-Taking Shaanxi Province as Example
}

\author{
Yuhong Wang ${ }^{1, \mathrm{a}}$, Gang Ye ${ }^{2, \mathrm{~b}, *}$ Ruirui Zhang ${ }^{3, \mathrm{c}}$ \\ 1, 2,3 Xi' an University of Technology, Xi'an, Shaanxi, China

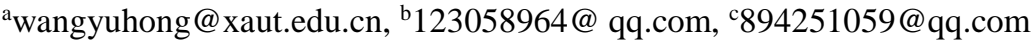

\begin{abstract}
International science and technology cooperation is the key elements in the construction of Silk Road Economic Belt. International science and technology cooperation of Shaanxi Province has made great achievements, meanwhile some disadvantages still exist. It is necessary to promote the path exploration of international science and technology cooperation in Shaanxi, through establishing national major project cooperation mechanism, deepening cultural and technological exchanges among countries along Silk Road, building an open financial support system and accelerating the construction of international science and technology cooperation platform.
\end{abstract}

Keywords-Path exploration; Silk Road Economic Belt; International science and technology cooperation

\section{INTRODUCTION}

A. The Comprehensive Development of International Science and Technology Cooperation is the Right Way to Inherit the Spirit of Silk Road

Shaanxi is the birthplace of Chinese civilization, also the combination of agricultural civilization and animal husbandry civilization. As early as the beginning of civilization, sericulture and silk weaving has become prosperous in Shaanxi. During the Warring States Period, Wushiluo, a merchant of Qin State, broke the earliest Silk Road [1]. At the time of Emperor Wu of Han Dynasty, Zhang Qian was sent to the west countries, who made the connection of east and west civilizations. In Tang Dynasty, Chang'an became the world center of science and culture, and ushered the golden age of Silk Road. In the 21st century, when we carry out international science and technology cooperation along Silk Road Economic Belt, the spirit of peaceful coexistence and cooperation among various ethnic groups in ancient times become the civilized basis for development of international science and technology cooperation, and the innovation spirit of the starting point of Silk Road become the power source of the prosperity of international science and technology cooperation [2].

\section{B. To Carry out International Science and Technology Cooperation in Accordance with Law is the Inevitable Requirement of Building a Service-oriented Government}

Suitable social environment and legalized management system is necessary for carrying out international science and technology cooperation. At present, China is working hard to build a service-oriented government. With the development of international science and technology cooperation under the background of building "One Belt One Road", the government should offer proper guidance and service, which shall rely on the scientific formulation and effective implementation of law and policy [3]. In specific terms, it includes confirming the relationship between subject and object of international science and technology cooperation, regulating the contents of cooperation, combining the legislation, law enforcement and justice into trinity system, and changing the traditional experience-type management into legalized management, to provide long-lasting and general preferential public service for all countries along the Silk Road.

\section{To Carry out International Science and Technology Cooperation Actively is an Important Way to Enhance the Competitiveness of Cooperation Parties}

In the report of the 18th National Congress of Communist Party of China, scientific and technological innovation is the strategic support of improving social productivity and comprehensive national strength, and must be placed in the core position of national development. The innovation of science and technology cooperation requires the cooperation and promotion among government, enterprises, universities and research institutions. First of all, the government along the Silk Road should be committed to transform the simple and divisional functions into integrated management and services, and establish a new international science and technology cooperation mechanism. Secondly, enterprises along the Silk Road should strengthen the technical management and service innovation, adopt a flexible and diversified way of cooperation, and apply the achievements of science and technology cooperation to social practice. Thirdly, universities and research institutions along the Silk Road should play the role of 
technological innovation and cultural communication, take the advantages of knowledge accumulation, and strengthen basic and frontier research.

\section{BASIC PATH AND INFLUENCING FACTORS OF INTERNATIONAL SCIENCE AND TECHNOLOGY COOPERATION IN SILK ROAD ECONOMIC BELT}

\section{A. Basic Path}

The basic path of international science and technology cooperation includes the following: Firstly, independent technological innovation. Although international science and technology cooperation emphasizes the combination of technology, having key and core technology can help one occupy the competitive advantage in the process of cooperation International science and technology cooperation along the Silk Road concerns national economy and people's livelihood, includes not only aerospace, aviation and other national strategic technologies, but also agricultural, medical and environmental technologies. Enterprises must develop the technology of independent IP rights to have a strong technical competitiveness. Secondly, joint research and development. During international science and technology cooperation, through joint study and mutual learning, parties owning advanced technology and those owning relatively backward technology may together develop new products, create a cluster network, and optimize the technical system. Thirdly, transnational mergers and acquisitions. The essence of transnational mergers and acquisitions is the expanding process of advanced technology and management experience. By participating the market competition of other countries, transnational mergers and acquisitions can break the original market equilibrium state, force the technically backward enterprise to improve management, thus promote the resource flowing to enterprises of high efficiency and improve the overall competitiveness of the industry. Fourthly, international strategic technology alliance. The technology alliance has a tight structure, efficient cluster innovation and consistent technology progress. The establishment of technology alliance will help promote the combination of knowledge capital and industrial capital, forward the development and diffusion of new technology, and improve the innovation of science and technology cooperation. Fifthly, construction of science and technology park. The science and technology park is an important place to integrate scientific and technological resources and realize industrial accumulation. In order to promote the development of science and technology park in China and keep pace with international practice, it is necessary to carry out the cooperative innovation of various parks [4]. The government should plan to build a series of parks owning key and core technologies, and improve the level of science and technology cooperation along the Silk Road.

\section{B. Influencing Factors}

The influencing factors regarding path selection of international science and technology cooperation mainly include the following: Firstly, target factor. The main participants of international science and technology cooperation include government, enterprises, universities and research institutions, etc. Different parties have different choices based on their own interests. As the external thrust of science and technology cooperation, the government is more concerned with science and technology progress and public interest. Enterprises' choice of cooperation path is determined by weighing the risk and income [5]. Universities and research institutions pay more attention to the form of cooperation results, and focus on improving the level of science and technology research. Secondly, resource factor. International science and technology cooperation exists the problem of scarcity and uneven distribution of resources. The popularity of local protectionism leads to the division by layer of science and technology resources. Meantime, due to the asymmetry of resource possession and information acquisition, related parties take the monopoly of resource possession, which will affect the regional distribution and scale of science and technology cooperation. Thirdly, benefit factor. In the end, international science and technology cooperation should produce the technical and commercial value, thus the input and output factor, and market demand and policy conformity must be considered [6]. Close and long-term cooperation can increase the possibility of technology development success, and to a certain extent, avoid less efficient output, and realize the effective transfer of knowledge to enterprises. Fourthly, risk factor. In the process of international science and technology cooperation, high-tech and high profit is always accompanied by high investment and high risk. The cooperative parties should judge the risks that may occur upon choice of different cooperation path, in order to reasonably share the risk and responsibility among cooperative parties.

\section{PRACTICE AND EVALUATION OF SHAANXI INTERNATIONAL SCIENCE AND TECHNOLOGY COOPERATION IN SILK ROAD ECONOMIC BELT}

\section{A. Practice and Experience}

Since Shaanxi Province was designated as the starting point of the Silk Road, the development of science and technology cooperation between Shaanxi and countries and regions along the silk road is gradually growing and mature. In the joint development research and scientific and cultural exchange, China(Xi'an) Silk Road Research Institute, University Union of the New Silk Road, and the Silk Road Economic Belt Cooperative Innovation Center have been established in succession in Shaanxi. In transnational investment, Zhongda Oil Company, which is located in Kyrgyzstan, is funded by Shaanxi Coal Chemical Group; Zhongneng Oil Exploration Co., Ltd. is the subsidiary company of Yanchang Oil, the leading enterprise in Shaanxi; and Sino-Kazakhstan Aiju Farming Products Processing Zone invested by Shaanxi Aiju Group has been constructed in Kazakhstan. In the construction of science and technology park, Sino-Russian Silk Road Innovation Park and Central Asia Silk Road Industrial Park 
have been settled down in Shaanxi. Besides, Sino-Kyrgyzstan Petroleum Refining Industrial Park, Sino-Kazakhstan Textile Industrial Park and Sino-Kazakhstan Agricultural Cooperation Park have been build in Central Asia. In infrastructure construction, the construction of Weibei Industrial Area, protection of the Ruins of Chang'an in Han Dynasty, and the project of Eight River Nourishing Chang'an have been carried out. Chang'an International Freight Train and Silk Road Tour Train between China and Central Asia have been operated for 3 years. Xi' an Xianyang International Airport opened 12 international direct routes. The international and domestic code of Xi'an Harbor has officially entered into the International Multimodal Transport System.

\section{B. Insufficiency and Defect}

First of all, the construction of major cooperation project is lagging behind. The working mechanism of promoting science and technology cooperation and integration of major cooperation project among government, enterprises, universities and research institutions is still not perfect. Small and micro enterprises lack persistent policy support to achieve further results in the projects involving people's livelihood. Secondly, scientific and cultural communication is not adequate. Professional talents of engineering, scientific research and management are concentrated in universities and institutions, while high-level and skilled talents in enterprises involved in science and technology cooperation along Silk Road are scarce, talents familiar with the culture, customs, laws and regulations in Central Asia are also poor. Thirdly, the investment and financing channels of international science and technology cooperation are weak and not clear. The financial support to international science and technology cooperation in Shaanxi is primarily based on financial expenditure, and has not formed a complete system. Special financial fund has not been set up to support the high-tech cooperation between local parties and countries along Silk Road. The existing loans concerning Sino-Central Asia projects are mainly short-term and limited-scale commercial loans, which can not meet the demand of enterprises to carry out science and technology cooperation. Fourthly, the development of international science and technology cooperation platform is slow. Due to the limited development and cooperation platform, participation into major scientific research projects is also limited. Unilateral technology trade is still the main form of international technology trade, the multilateral communication mechanism is missing.

\section{PATH OPTIMIZATION OF SHAANXI INTERNATIONAL SCIENCE AND TECHNOLOGY COOPERATION IN SILK ROAD ECONOMIC BELT}

With the global trend of knowledge economy, international science and technology cooperation and innovation begin to show its property of public product. On one hand, we should build a synergistic cooperation system involving government, enterprises, universities and research institutions and reduce the risk of cooperation and investment; on the other hand, it is necessary to strengthen the government's basic, guiding and bridge-building role in cooperation resource allocation, to choose cooperation path suitable for the provincial conditions.

\section{A. Establishing National Major Project Cooperation Mechanism along Silk Road}

In the process of international science and technology cooperation, Shaanxi government should play the role of guidance and coordination as the center of science and education in western area, integrate intellectual resources to participate in forward-looking major science and technology cooperation projects, support the development of characteristic and advantageous disciplines, and establish complete management system and implementation procedure for major science and technology cooperation projects, which include project planning, coordination, management and fund supervision.

\section{B. Deepening Cultural and Technological Exchange among Countries along Silk Road}

First of all, we should make full use of China-Asia-Europe Exposition and Chinese Western International Exposition to strengthen the exchange of science and technology cooperation, build cultural and technological exchange demonstration and training base with Silk Road characteristics, and carry out the trainings on advanced technology, technology management, laws and regulations, and nationality customs of countries along Silk Road. Secondly, we should gradually establish a rational incentive mechanism for talents, and focus on multichannel introduction of talents who are familiar with international rules and market operation. Thirdly, we should strengthen the propaganda and recommendation of cultural and technological exchange along Silk Road by using traditional and contemporary media, and build science and technology cooperation results exhibition and promotion center in countries along Silk Road.

\section{Building an Open Financial Support Mechanism for Science and Technology Cooperation along Silk Road}

Firstly, Shaanxi government should lead to build a multilevel investment system involving state revenue, local revenue and private capital, establish more independent or cooperative financial support funds, and emphasize on supporting key technologies which have market potential value and concern people's livelihood. Secondly, we should promote domestic financial institutions to actively focus on and participate in the science and technology cooperation along Silk Road, attract international financial institutions to set up branches in Shaanxi, and try to carry out the offshore financial business with countries in Central Asia. Thirdly, we need to speed up the cooperation process in such financial services as securities, insurance and trust between Shaanxi and other countries, establish the financial cooperation platform for public welfare, and build up tridimensional financial supporting network. 
D. Accelerating the Construction of International Science and Technology Cooperation Platform along Silk Road

First of all, web portals of Shaanxi Silk Road International Science and Technology Cooperation Platform should be established, which includes modules of information exchange, intermediary service, project cooperation, and policy and regulation, etc. Meanwhile, Shaanxi Silk Road International Science and Technology Cooperation Foundation Database should also been set up, to realize the sharing of information resources and complementation of service function. Secondly, it is necessary to construct intermediary service system for cooperation, encourage technical personnel to participate in intermediary service, reinforce professional training, in order to provide policy consultation, technical guidance, asset evaluation and other services. Finally, Shaanxi Silk Road Technology Innovation Alliance should be build up, which can organize information exchange regularly, propose policy suggestions timely, and promote the sharing of resources rationally.

\section{CONCLUSION}

Carrying out international science and technology cooperation is important to the construction of "One Belt One Road" and to the social and economic development of countries along the Silk Road. As the new starting point of Silk Road Economic Belt, Shaanxi should recognize its advantages and potential in the practice of international science and technology cooperation, combine technical innovation and technical cooperation, establish the cooperative orientation of people's livelihood and public service, emphasize the fundamental role of the government and the participation of enterprises, universities and research institutions, innovate the path of international science and technology cooperation, in order to provide support for sustainable and integrated development of Shaanxi Province.

\section{ACKNOWLEDGEMENT}

This research was financially supported by Shaanxi Soft Science Research Project: Research on Mode Choice and Legal Protection of Shaanxi International Science and Technology Cooperation and Exchange as the New Starting Point of Silk Road Economic Belt (2016KRM098), and Xi'an Soft Science Research Project: Research on Science and Technology Exchange and Cooperation in the Construction of Silk Road Economic Belt (SF1503 (1)).

\section{REFERENCES}

[1] Xiang Chun. Wushiluo-the first famous businessman on the Silk Road, No.2, Journal of Chinese Historical Geography, 1996, pp.86.

[2] Wang Yuhong, Yegang. Strengthen the Cooperation of International Science and Technology, Boost Constructing Xi'an as New Starting Point of Silk Road Economic Belt, vol.30, No.3, Journal of Shaanxi Academy of Governance, 2016, pp.41-44.

[3] Bao Yuncheng. Legal Thinking of the Construction of "One Belt, One Road", No.1,Forward Position, 2015, pp.65-69.

[4] Huang Zhijian, Zhang Qinghua. Research on collaborative innovation capacity of Science Park, vol.32, No.3, Scientific Management Research, 2014, pp.25-28.

[5] Ye Baozhong, Ye Zirong. Research on Comparison and Selection of Chinese Technology Transfer Service Model, vol.242, No.2, Guizhou Social Sciences, 2010, pp.98-103.

[6] Yang Xu, Yu Bo. Research on Transformation Mode of Chinese Scientific and Technological Achievements, No.8, Study \&Exploration, 2012, pp.106-108. 